\title{
Monitoring restored riparian vegetation: how can recent developments in remote sensing sciences help?
}

\author{
S. Dufour ${ }^{(1), \star}$, I. Bernez ${ }^{(2,3)}$, J. Betbeder ${ }^{(1)}$, S. Corgne ${ }^{(1)}$, L. Hubert-Moy ${ }^{(1)}$, \\ J. Nabucet ${ }^{(1)}$, S. Rapinel ${ }^{(1)}$, J. Sawtschuk ${ }^{(2)}$, C. Trollé(1,2)
}

Received December 17, 2012

Revised July 15, 2013

Accepted July 18, 2013

\section{ABSTRACT}

Key-words: Riparian vegetation restoration projects require appropriate tools to monremote sensing, itor actions efficiency. On a large scale remote sensing approaches can riparian provide continuous and detailed data to describe riparian vegetation. In vegetation, this paper, we illustrated recent developments and perspectives for ri$U A V$, LiDAR, radar parian vegetation monitoring purposes through three examples of image sources: Light Detection And Ranging (LiDAR), radar and Unmanned Aerial Vehicule (UAV) images. We notably focused on the potential of such images to provide 3D information for narrow strips of riparian vegetation with high temporal resolution to allow fine monitoring following restoration program. LiDAR data allows canopy structure identification with a high accuracy level and automatic classifications for heterogeneous riparian corridors. Radar images allow a good identification of riparian vegetation but also of the structure and phenology of vegetation through time with an analysis of the Shannon entropy of the signal. The UAV system used here is a very flexible approach that can easily provide RGB mosaic but also a local digital surface model with very high spatial resolution. Lastly, we discuss the advantages and limitations of each approach from an applied perspective, in terms of flexibility, resolution and technicality.

\section{RÉSUMÉ}

Suivre la restauration de la végétation riveraine : comment les développements récents de la télédétection peuvent-ils aider?

Mots-clés : télédétection, végétation riveraine, UAV, LiDAR, radar
Le suivi des projets de restauration de la ripisylve nécessite des outils spécifiques. Dans cet article, nous illustrons et discutons comment les développements récents dans le domaine de la télédétection permettent une description détaillée, continue et à large échelle des ripisylves restaurées à partir de trois exemples d'images : laser (LiDAR), radar et drone. Nous analysons notamment la capacité et le potentiel de ces images à fournir une information volumétrique de ripisylves étroites avec une forte résolution temporelle afin de permettre un suivi fin des actions de restauration. Les données LiDAR permettent une description de la structure de la canopée avec une très bonne précision ainsi qu'une classification automatique des ripisylves hétérogènes. Les images radar permettent une bonne identification non seulement de la végétation riveraine mais aussi de sa structure et de sa phénologie par analyse de l'entropie du signal. La technologie drone déployée ici est très flexible et facile à mettre en œuvre; elle donne accès à des mosaïques de photographie à très haute résolution spatiale et à faible résolution

(1) UMR CNRS 6554 LETG Rennes COSTEL/Département de Géographie, Université Rennes 2, France

(2) INRA UMR 0985 Ecologie et Santé des Ecosystèmes ESE, France

(3) INRA AgroCampus Ouest, France

* Corresponding author: simon.dufour@univ-rennes2.fr 
spectrale. Mais elle permet aussi de générer facilement un modèle numérique de surface très précis. Les avantages et les inconvénients respectifs des différentes approches sont finalement discutés dans une perspective opérationnelle. II en ressort que le choix de l'une ou l'autre doit essentiellement être guidé par l'objectif du suivi et les moyens disponibles.

\section{INTRODUCTION}

Riparian vegetation has central position in the river ecosystem. It stands at the interface of terrestrial and aquatic environments and therefore plays a crucial role both for the ecological integrity of river courses and for the social values of fluvial corridors (Malanson, 1993; Naiman et al., 2005; Wasson et al., 2010; Feld, 2012). Over the last decades restoration has become a complementary approach to conservation and protection practices (Ormerod, 2004; Dufour and Piégay, 2009). However, if restoration principles are now quite well established, some aspects of restoration projects still need improving (Palmer et al., 2005); the monitoring process is clearly one of these. Indeed, both scientists and managers need appropriate tools to monitor riparian vegetation: the latter for a quantitative evaluation of funded action efficiencies and the former for a detailed understanding of vegetation pattern and dynamic follow-up of restoration. Site or reach scale projects have numerous tools to assess riparian vegetation response to restoration practices (Munné et al., 2003; Coroi, 2006; Brooks et al., 2009). However, large scale projects need specific tools, capable of generating continuous and detailed data set along several river segments or at network scale (Tormos et al., 2011). It is thus a major challenge to describe large scale riparian vegetation (semi-)automatically in terms of species and cover but also volume, structure and biomass. Recent developments in remote sensing and geographic information systems (GIS) may offer a good opportunity to provide useful information and indicators on such large scales (Goetz, 2006; Johansen et al., 2007a; Yang, 2007; Johansen et al., 2010; Aguiar et al., 2011; Dufour et al., 2012). In a recent review, Carbonneau and Piégay (2012) clearly showed that in the area of fluvial remote sensing radar, LiDAR and UAV approaches represent the most recent, and least used and completed systems for applied uses in river environment. Thus in this paper, we illustrated recent developments and perspectives for riparian vegetation monitoring purposes by means of three examples of image sources: Light Detection And Ranging (LiDAR), radar and Unmanned Aerial Vehicule (UAV) images. The applications of LiDAR, radar and UAV systems are numerous, including topographic mapping, surface movement detection, defense and security monitoring, as well as environmental monitoring... In this study, we specially focused on the potential of such images to provide 3D information for narrow strips of riparian vegetation with high temporal resolution to allow fine monitoring following the restoration program. We discussed the advantages and limitations of each approach from an applied perspective.

\section{AREAS UNDER STUDY}

All images are about two small river systems located in the northwest of France: the Oir river (for UAV images) and the Couesnon river (for LiDAR and Radar images) (Figure 1). The Oir river is a $20-\mathrm{km}$ long tributary of the Sélune river, on which ecological surveys have been carried out for 20 years to restore the salmonid population quality regarding the quality of their habitat (Forget et al., 2013). The Couesnon is a small 97-km long coastal river. In this work, we studied a 17-km long, downstream section of the Couesnon, located in "Zone Atelier Armorique" (Pleine-Fougères site), a site that is part of the ILTER multidisciplinary research network. In this section, the Couesnon has an average width of $15 \mathrm{~m}$ and an average flow of $7.1 \mathrm{~m}^{3} \cdot \mathrm{s}^{-1}$. To reduce flooding, this section was channelized and dammed in 1969, with steep 3-m banks. Riparian woody vegetation consists mainly of woody vegetation trees or shrubs (Populus, 


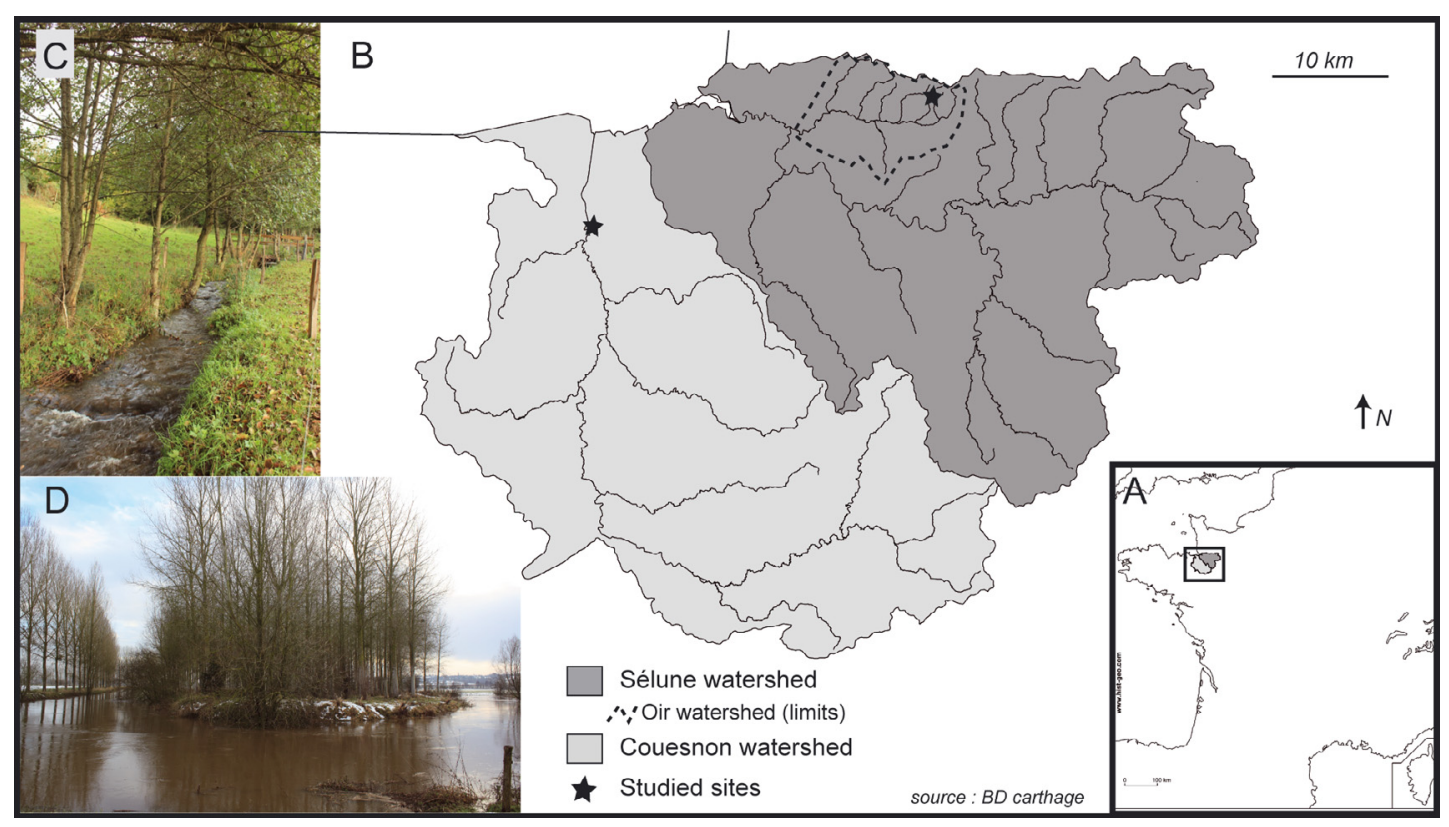

\section{Figure 1}

Location of reaches under study: A) watershed location, B) studied site location, C) Oir river and D) Couesnon river.

Salix, Alnus and Fraxinus). The Sélune river and the Couesnon river run into the Mont-SaintMichel Bay. Valley landscape is dominated by pasture and farming as regards both systems.

\section{MATERIAL AND METHODS}

\section{> LIDAR IMAGES}

Although conventional sensors have proven satisfactory for many ecological applications such as mapping land cover into broad classes and, in some biomes, estimating aboveground biomass and leaf area index ( $\mathrm{LAl}$ ) - they present significant limitations for some ecological applications (Lefsky et al., 2002). Their sensitivity and accuracy fall as aboveground biomass and leaf area index increase (Turner et al., 1999). They also cannot fully represent the three-dimensional spatial pattern of vegetation, because they produce only two-dimensional $(x$ and $y$ ) images.

Laser instruments such as LiDAR (Light Detection and Ranging) has been shown to be an alternative remote sensing technology, especially in systems where biomass accumulation is significant (Vierling et al., 2008). They increase the accuracy of biophysical measurements and extend spatial analysis into the third $(z)$ dimension, providing fine-grained information about the 3-D structure of ecosystems across broad spatial extents. Indeed, aiborne LiDAR sensors provide high-resolution topographic maps and accurate estimates of vegetation height, cover, LAl, aboveground biomass as well as canopy structure (for riparian vegetation see Dowling and Accad, 2003; Farid et al., 2006; Antonarakis et al., 2008a, 2008b; Geerling et al., 2009; Arroyo et al., 2010).

Fine-scale identification and mapping of riparian vegetation was undertaken in the PleineFougères site using airborne Laser Terrain Mapper (ALTM) data captured in March 2009, before leaves have grown, with an Optech Airborne Laser Scanner- Litemapper 5600. The LIDAR data characteristics are described in Table I. The LiDAR data acquisition was performed in the near infrared band $(1.064 \mu \mathrm{m})$, with a high spatial resolution and high accuracy, with, respectively, an approximately 4-point per square meter density and a height accuracy 
Table I

Characteristics of image sources and processing (source: Géophénix, 2009; http://www.sensefly.com); information about LiDAR differs according to each survey; here, we indicated the values for the studying flight.

\begin{tabular}{|c|c|c|c|}
\hline & LiDAR & Radar & UAV \\
\hline Spatial resolution & $4 \mathrm{pts} / \mathrm{m}^{2}$ & $\begin{array}{c}\text { Azimuth: } 2.2 \mathrm{~m} \\
\text { Range: } 1.48-3.49 \mathrm{~m}\end{array}$ & 0.02 to $0.5 \mathrm{~m}$ \\
\hline $\begin{array}{l}\text { Horizontal and } \\
\text { Vertical accuracy }\end{array}$ & 0.3 and $0.12 \mathrm{~m}$ & & \\
\hline Spectral resolution & $1064 \mathrm{Nm}$ & & $\begin{array}{l}\text { Small format RGB } \\
\text { digital camera }\end{array}$ \\
\hline Polarization & & Dual (HH/VV) & \\
\hline $\begin{array}{l}\text { Pulse Rate } \\
\text { frequency }\end{array}$ & $150000 \mathrm{~Hz}$ & & \\
\hline Mode & & High resolution spotlight & \\
\hline Working area & $130 \mathrm{~km}^{2}$ & $100 \mathrm{~km}^{2}$ & Up to $10 \mathrm{~km}^{2}$ \\
\hline Flying altitude & $1.3 \mathrm{~km}$ & $514 \mathrm{~km}$ & $0.1 \mathrm{~m}$ to $1.5 \mathrm{~km}$ \\
\hline Cost & 20000 euros & $\begin{array}{c}\text { New acquisition: } 8775 \text { euros } \\
\text { Archive: } 4390 \text { euros }\end{array}$ & $\begin{array}{c}15000 \text { euros for the UAV } \\
\text { and software }\end{array}$ \\
\hline Fly time & $260 \mathrm{~min}$ & & $30 \mathrm{~min}$ \\
\hline $\begin{array}{l}\text { Scan or incidence } \\
\text { angle }\end{array}$ & $28^{\circ}$ & $\begin{array}{c}37^{\circ} \\
\text { (Right Ascending) }\end{array}$ & \\
\hline Temporal resolution & On-demand & 11 days & $<1$ day \\
\hline Date & 04/05/2009 & $\begin{array}{l}\text { 2012: } 19 / 04-30 / 06- \\
12 / 07-03 / 08-15 / 09\end{array}$ & 20/06/2012 \\
\hline $\begin{array}{l}\text { Software } \\
\text { needed }\end{array}$ & $\begin{array}{l}\text { Terra solid } \\
\text { eCognition }\end{array}$ & $\begin{array}{l}\text { PolSarPro; Nest (free) } \\
\text { PCI Geomatica }\end{array}$ & $\begin{array}{l}\text { Agisoft Photoscan } \\
\text { GIS software }\end{array}$ \\
\hline $\begin{array}{l}\text { Data processing } \\
\text { duration }\end{array}$ & 7 days & $\begin{array}{c}\text { Pre-processing: } 4 \text { hours } \\
\text { Processing and validation: } \\
6 \text { hours }\end{array}$ & $\begin{array}{l}\text { Mosaicking } 36 \text { images = } \\
\quad 0.5 \text { to } 1 \text { day } \\
\text { Generating digital surface } \\
\text { elevation }=0.5 \text { to } 1 \text { day }\end{array}$ \\
\hline $\begin{array}{l}\text { Critical step } \\
\text { or technical } \\
\text { requirement }\end{array}$ & $\begin{array}{c}\text { Technical skills } \\
\text { on ecognition } \\
\text { Computer memory }\end{array}$ & $\begin{array}{l}\text { Technical skills for geometrical } \\
\text { correction and polarimetry } \\
\text { information extraction } \\
\text { Require theorical basis } \\
\text { in radar and polarimetry }\end{array}$ & $\begin{array}{c}\text { Computer memory } \\
\text { increase with the number } \\
\text { of pictures }\end{array}$ \\
\hline
\end{tabular}

of about $\pm 0.1 \mathrm{~m}$. Forty-five lines were flown to cover the $150 \mathrm{~km}^{2}$ study area. LiDAR data were georeferenced to Lambert-RGF93/IGN-69 coordinates, using differential GPS measurements. The laser points $(X-, Y$-, $Z$ - coordinates) were then classified in ground and vegetation points with TerraScan software (Axelsson, 1999). Ground and higher vegetation points were used to derive respectively a high-accuracy Digital Terrain Model (DTM) and a Digital Surface Model (DSM), using the Nearest Neighbors (NN) interpolation method. The height image is the difference between DSM and DTM. The intensity image was calculated from mean intensity point values within grids of $0.5 \mathrm{~m} \times 0.5 \mathrm{~m}$ using nearest neighbor interpolation method.

\section{$>$ RADAR IMAGES}

We used a series of five TerraSAR-X satellite images (Table I). TerraSAR- $X$ is characterized by an active phased array $\mathrm{X}-\mathrm{Band}$ system, with a $9.65-\mathrm{GHz}$ center frequency , a near-polar orbit around the earth and is able to register images with a spatial resolution of approximately one meter, regardless of weather conditions or absence of daylight. Data can be acquired in numerous modes (SpotLight, StripMap and ScanSAR), depending on the spatial resolution 

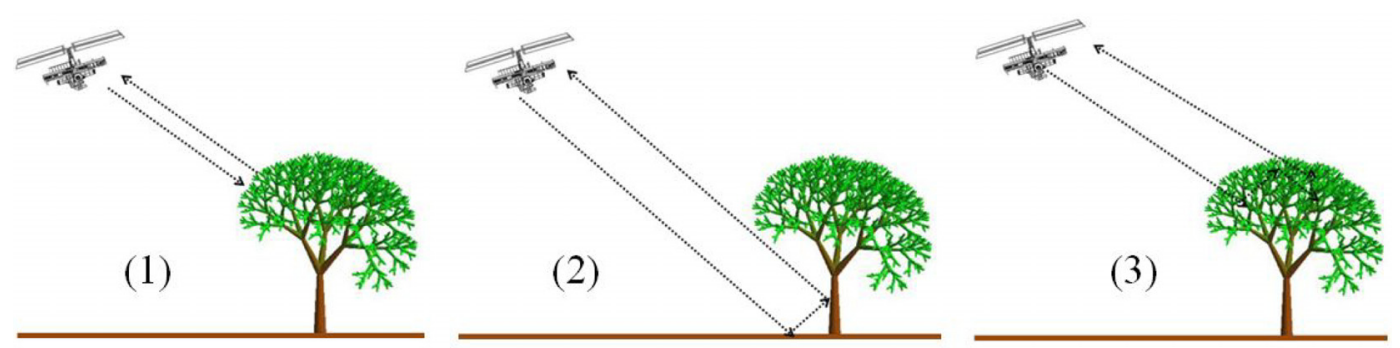

\section{Figure 2}

The three major scattering mechanisms studied with polarimetric data: (1) Single bounce from a plane surface backscattered towards the radar, (2) Double bounce from a flat surface that is horizontal with an adjacent vertical surface and (3) Volume scattering from randomly oriented objects.

and polarization required (Fritz et al., 2007). TerraSAR-X appears very promising for monitoring riparian vegetation because of its specificities (Lopez-Sanchez et al., 2009): shorter revisit time than previous radar sensors (11 days), a frequency band $(X)$ suited to the monitoring of changes in vegetation phenology, a phase information preserved for dual-polarization data acquired in single look slant range complex mode, which allows the extraction and use of incomplete polarimetric decomposition and a very high spatial resolution (below $3 \mathrm{~m}$ ), even for dual-polarization images, which appears suited to identifying and characterizing riparian vegetation.

Images were pre-processed in order to reduce speckle noise (Lee, 1981), and correct the topographic deformations using PolSARpro 4.2 (http://earth.eo.esa.int/polsarpro/) and Nest Dat 4C (http://nest.array.ca/web/nest) opensource software programs. Images were then georeferenced in the Lambert-RGF93/IGN-69 system, using 55 ground control points selected from aerial photography.

Polarimetric images are sensitive to object orientation and scattering properties. In synthetic aperture radar (SAR) polarimetry, the emitted and received states of polarization change during data collection $(\mathrm{HH}, \mathrm{HV}, \mathrm{VH}$ and $\mathrm{VV}$ for full polarimetric data), providing the phase and magnitude of the backscattered signal that is related to the material properties of the studied object (roughness, orientation, structure...). Although three major scattering mechanisms can be studied (Figure 2), in our case we only investigated the single and double bounce scattering mechanisms. Considering the backscattering intensities of the five dual-polarization TerraSAR-X images (HH/VV), we selected the real-valued intensity for each of the two scattering matrix elements. From these last two intensity images, we can only obtain an incomplete covariance matrix, since the HV image is not available. Nevertheless, we extracted several polarimetric parameters that are useful to characterize the vegetation structure, such as the Shannon entropy, Alpha angle, ratios, etc... (Lee and Pottier, 2009).

The riparian vegetation was extracted using the Shannon Entropy (SE) parameter (Lee and Pottier, 2009). SE is a measure of disorder encountered in polarimetric SAR images. SE can be decomposed as the sum of two terms: the intensity contribution that depends on the total backscattered power and the polarimetric contribution. In other words, the SE allows measuring the number of mechanisms that interact in a pixel and the power of each ones. Hence, if riparian vegetation is quite developed and complex, the number of mechanisms and their backscattering intensities are high and the entropy image values will also be high. In this study, the riparian vegetation was automatically extracted by applying threshold segmentation on the SE image.

\section{$>$ UAV IMAGES}

We used a series of UAV 36 RGB digital images taken in June 2012 over a $1.5 \mathrm{~km}$ long reach by a UAV Swinglet CAM, marketed by senseFly and equipped with a 12 MP compact camera with a $24 \mathrm{~mm}$ focal length (in 35-mm equivalent) (see http://www.sensefly.com) (Figure 3A). 

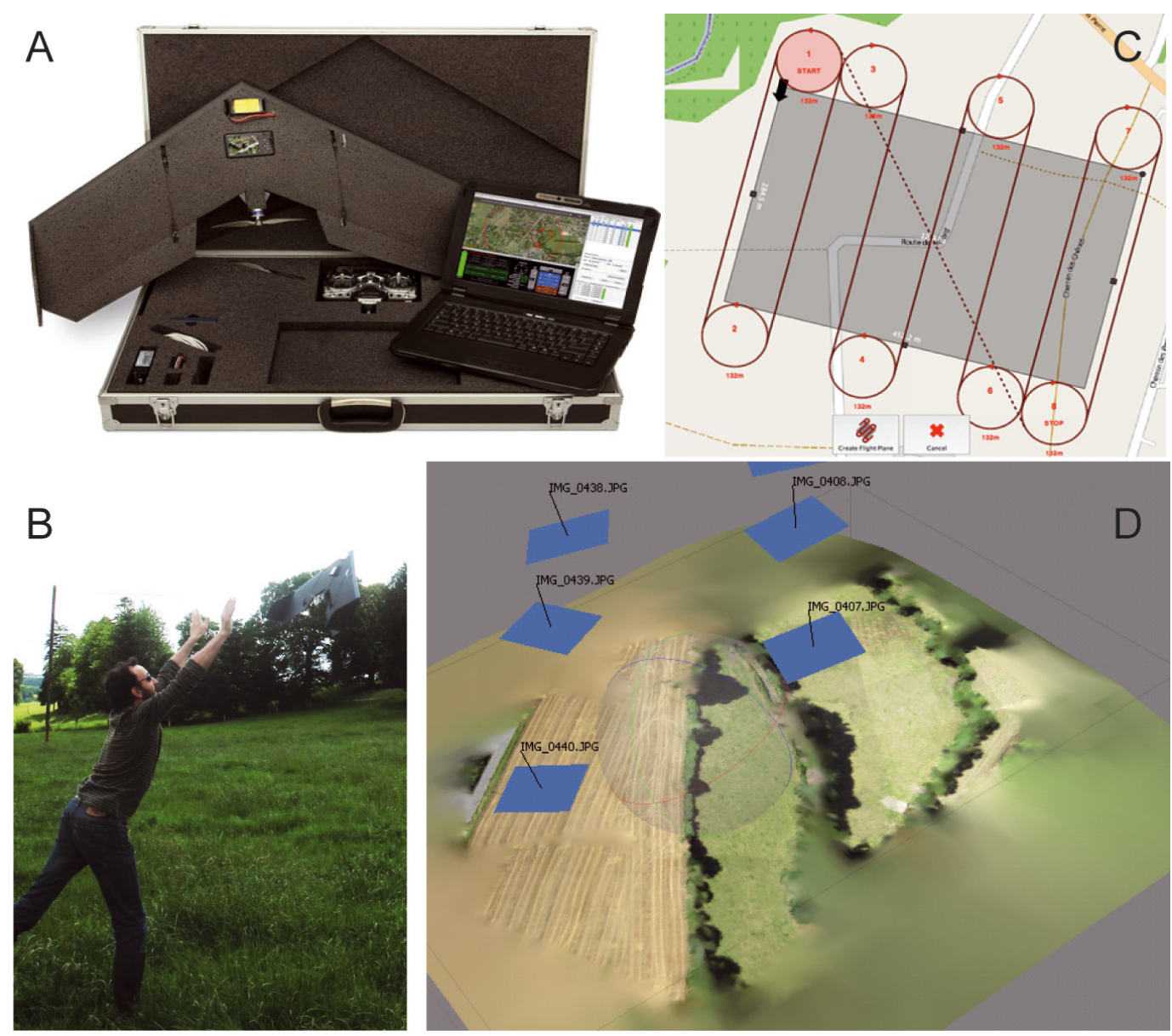

Figure 3

UAV A) accessories (model sensefly swinglet cam), B) take-off, C) screenshot of flight plan (e-mo-tion software), D) screenshot of mosaicking process (Agisoft PhotoScan software).

Due to the recent development of UAV technology, a large range of systems is available (see Hardin and Jensen, 2011 and Carbonneau et al., 2012 for recent reviews). We used a micro UAV well adapted to a monitoring program, notably because it is ready to deploy systems with autonomous take-off, flight and landing. Flight elevation is between 0.1 and $1.5 \mathrm{~km}$, with respective spatial image resolutions between 0.02 and $0.50 \mathrm{~m}$. We set the overlap between pictures at $80 \%$ and the spatial resolution at $5 \mathrm{~cm}$. From these 2 requirements, all flight characteristics (trajectory, altitude and number of images) are automatically managed in e-mo-tion software (Figure 3C).

The mosaicking process and digital surface model (DSM) generation were performed with the Agisoft PhotoScan software (http://www.agisoft.ru/) (Figure 3D). With no ground control points, absolute accuracy is about $5 \mathrm{~m}$, thus we orthorectified the mosaic with the ArcGIS software based on orthophotograpies provided by the Institut Géographique National (IGN).

\section{RESULTS}

\section{$>$ LIDAR}

Direct visualization of the 3D point cloud data-sets with color-maps can been used to enhance visualization of the point cloud data for interactive inspection and initial understanding of the spatial patterns of riparian vegetation. This provides a simple way to identify canopy structure with a high accuracy level (Figure 4). The analysis of two simple canopy structure 




Figure 4

$3 D$ view of riparian vegetation derived from the LiDAR cloud points: top canopy in cyan, herbaceous strata in purple and branches in yellow points correspond respectively to 1, 2 and 3 returns according to vegetation structure (black areas correspond to no-return area, e.g. water bodies). 


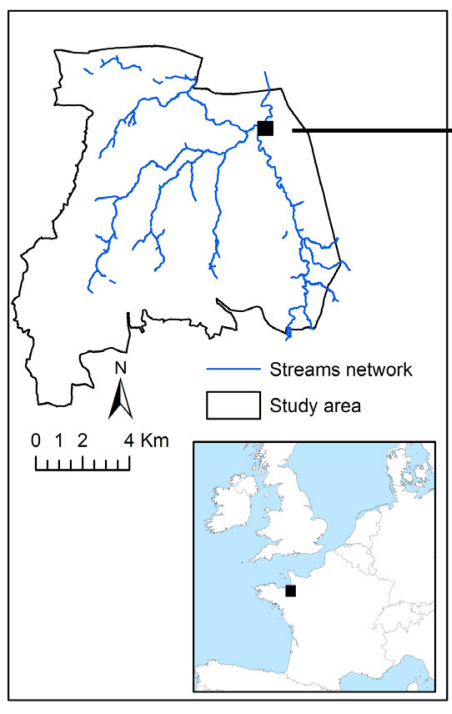

Figure 5

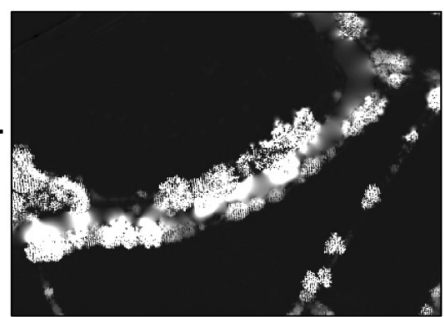

a

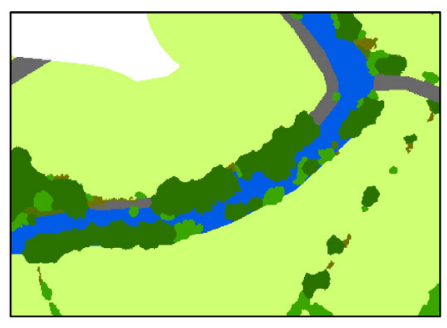

C

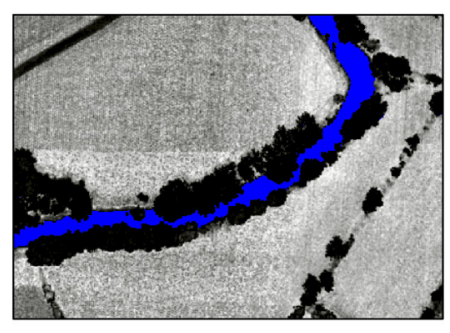

b

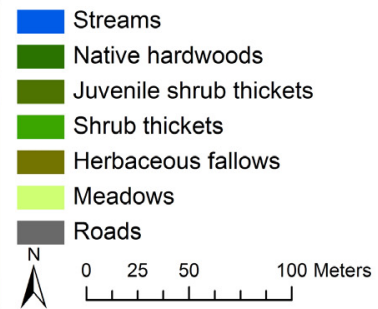

(1)

Riparian vegetation map from LiDAR data: (a) height image; (b) intensity image; (c) vegetation map.

measurements, that is, canopy height and cover, highlights the position, extent, quantity, type, and connectivity of the aboveground components of vegetation, which brings information about canopy function, vegetation-related habitat conditions for wildlife (Hansen and Rotella, 2000), or bank erosion.

For monitoring restored riparian vegetation, accurate spatial information of riparian vegetation patterns needs to be derived in automatic fashion. Automatic classifications regarding heterogeneous riparian corridors data can be performed at fine scales using LIDAR data. We applied a supervised oriented-object classification on the LiDAR data acquired on the PleineFougères site, by considering seven land cover classes, including five vegetation classes, roads and water (Figure 5). To that end, water bodies and roads were first respectively identified by applying a multi-threshold segmentation on the intensity image, and extracting the road layer from the IGN ${ }^{\circledR}$ BD TOPO database. Then, vegetation strata were determined by applying a multi-threshold segmentation from the height image. Classification results were assessed using ground data collected over 215 field plots and height values estimated from LiDAR data processed via photo-interpretation. Although the classification method produced very good levels of accuracy (Global Kappa index $=0.93$ ), results can be improved by using available object parameters that have not yet been exploited, such as spectral, texture, context and shape information.

\section{$>$ RADAR}

The first output (Figure 6) is a composite color derived from the incomplete covariance matrix of the dual polarization (HH/NV) TerraSAR-X image acquired on 14 April 2012 at the study area (Zone Atelier Armorique, France). Crops can be easily identified, because at this time of year they are very sensitive to the $|\mathrm{HH}-\mathrm{VV}|$ component (double bounce), due to their size and structure (beginning of the vegetative growth with considerable contribution to ground structure). Permanent meadows are also discriminated by mixing single and double bounce mechanisms. Bare soils or soils with low vegetation cover, which are quite smooth and thus associated to the single bounce mechanism, can be inventoried. Riparian vegetation is well identified as its components are characterized by complex properties (Different sizes, orientations, structures, vegetation developments, etc.), hence different scattering mechanisms. For example, a poplar grove, which runs along the river bank, looks white because backscattering intensity values are high for both polarizations ( $\mathrm{HH}$ and VV). 


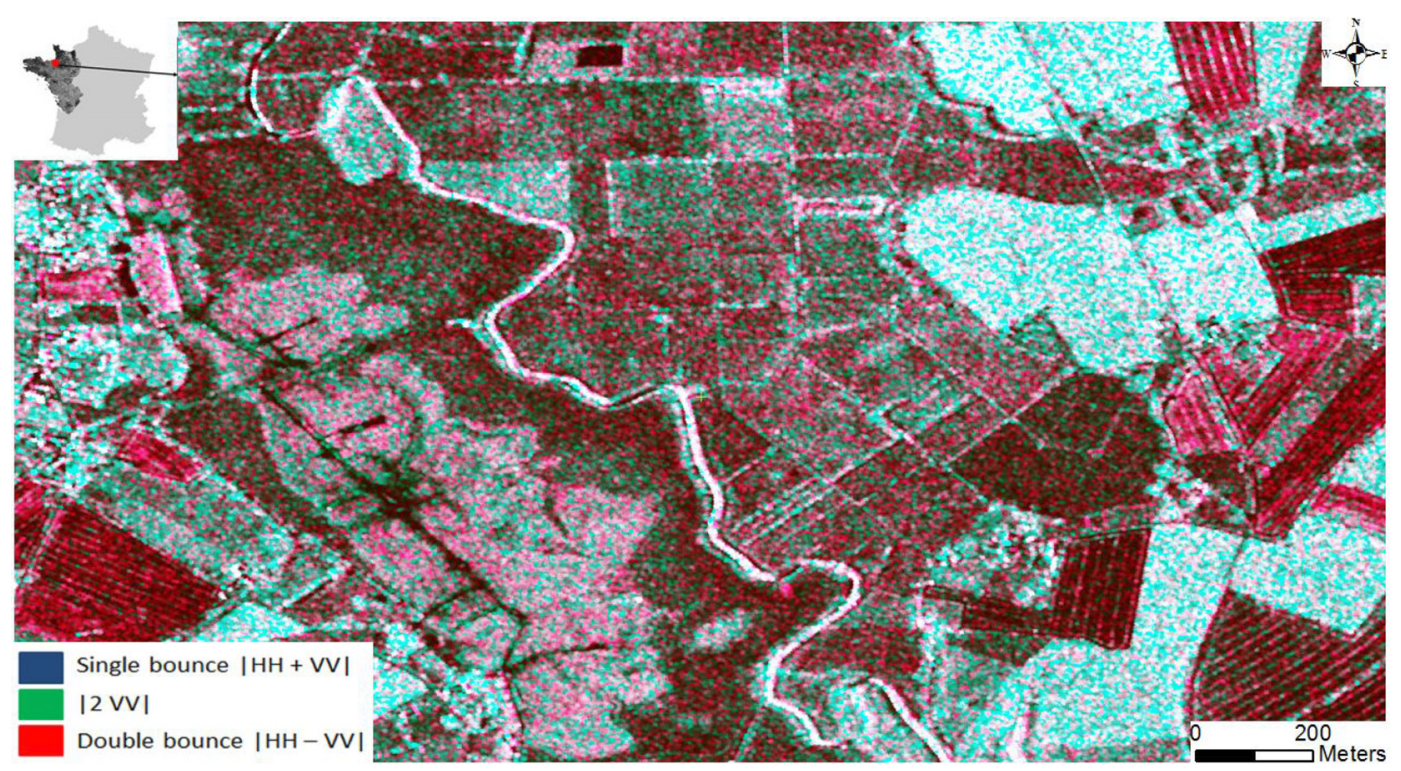

\section{Figure 6}

Composite color of the TerraSAR-X image (HH/VV) acquired on 14 April 2012 (Blue: $|H H+V V|$ component (single bounce); Green: |2VY component; Red: |HH - VV component (double bounce)). In red, we can see crops, such as cereals; in magenta permanent meadows; and in blue and cyan, bare soils or soils with low vegetation cover; here riparian vegetation appears in white and green (poplar grove and shrubs).

The analysis of the Shannon Entropy (SE) image is not only interesting to extract riparian vegetation but also to identify its vegetation structure (Figure 7). Riparian vegetation presents high SE values, due to the high number of scattering mechanisms and their related intensities (on tree structures). The vegetation structure is analyzed with an hemispherical photography which characterizes plant canopy geometry and permit LAI (Leaf Area Index) extraction. SE evolution could be related to the change in riparian vegetation phenology. Indeed, the SE values increase with the complexity of the riparian vegetation structure. In the western part of the river, shrubs appear on the SE image after leaves have grown ( June).During the following months, shrub vegetation becomes denser and more complex, which increases SE values, allowing their being identified and extracted. Regarding the high repetitivity of TerraSAR-X, this tool proves interesting to monitor the riparian vegetation and identify areas to restore.

\section{$>$ UAV}

Based on a 15-min flight and 36 pictures captured by the micro UAV swinglet cam, we built a RGB mosaic of a 1.5-km long reach of the Oir river (Figure $8 \mathrm{~A}$ ). Due to the flight altitude $(150 \mathrm{~m})$ and mosaicking process, the spatial resolution of the mosaic is about $7 \mathrm{~cm}$. The centimetric scale resolution gives access to numerous features of the riparian corridor (channel, trees...). For example, pieces of wood that drop down in the channel after vegetation clearance can be accurately identified (Figure 8B). Some problems have been encountered during mosaic generation. Indeed, the presence of clouds or small gaps between pictures can make it difficult to automatically generate the mosaic. The Agisoft software deals properly with differences of brightness between pictures (contrary to what was observed by Lejot et al., 2007) but some distortions were noticed on the mosaic margins (Figure 8A).

A digital surface elevation (DSM) has also been automatically generated using the Agisoft software. The vertical resolution corresponds to the mosaic spatial resolution (see for example the pile of wood on Figure $8 \mathrm{C}$ and $8 \mathrm{D}$ ). 
a)

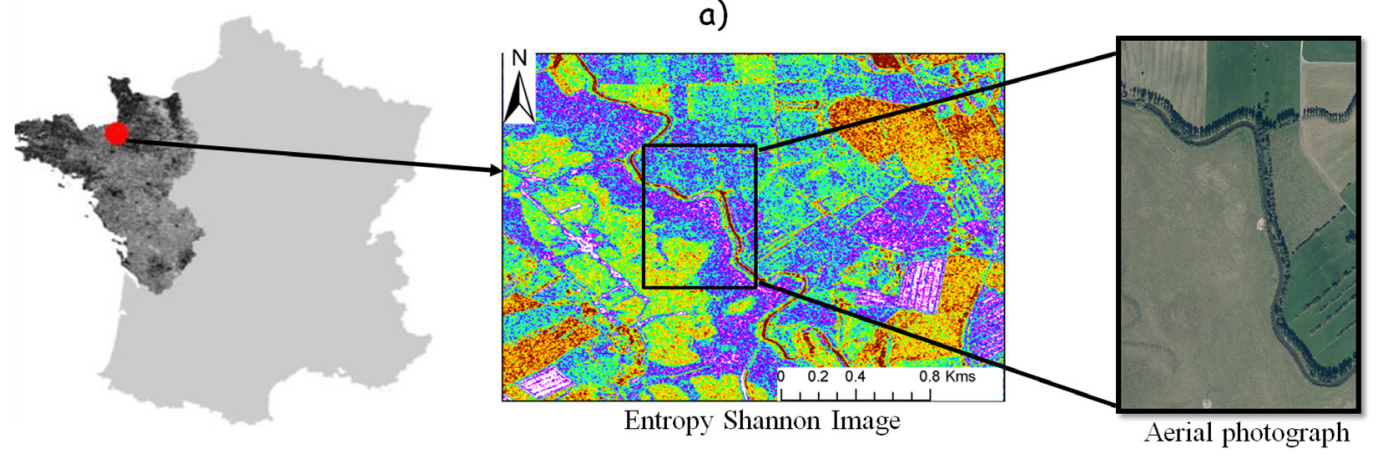

b)

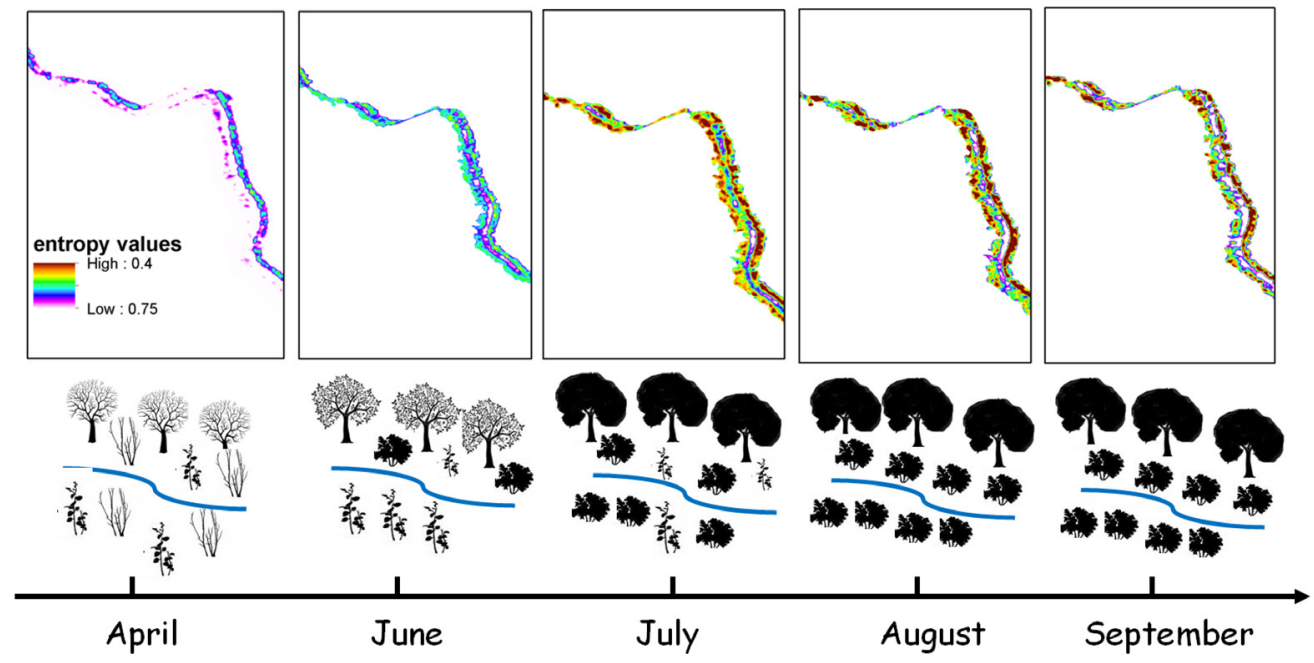

Figure 7

Riparian vegetation monitoring, with the Shannon Entropy parameter derived from TerraSAR-X images (Dual-polarization): a) Riparian vegetation extracted from the image registered in July and b) Evolution of the intra-annual riparian vegetation during the year 2012.

\section{DISCUSSION}

Over the last few decades, image analysis of riparian vegetation has undergone a huge evolution due to an increase in sources and to the type of imagery (Yang, 2007; Dufour et al., 2012; Fernandes et al., 2013). Very high resolution satellite images, such as IKONOS or GeoEye, combine high spatial resolution with a broad areal coverage; and image analysis has made great progress resulting in an increase in computing capacity, GIS techniques and advanced image analysis software (Goetz, 2006; Johansen et al., 2007a; Tormos et al., 2011). The emergence of new technologies makes it possible to have access to new information, such as forest stand structure, thus improving riparian description (Johansen et al., 2011). In this paper, we illustrated some recent developments in remote sensing tools that could be used to monitor riparian vegetation in restoration context. We show that LiDAR, radar and UAV images notably allow a 3 dimension characterization of vegetation through digital surface model regarding UAV, point cloud concerning LiDAR and Shannon entropy for radar.

Different systems obviously present different relative advantages/disadvantages (Table II). As regards UAV and LiDAR, spatial resolutions, and thus the description of the structure, are very fine (Johansen et al., 2011; Carbonneau et al., 2012). The revisit time of TerraSAR-X (11 days) and the flexibility of UAV permit scheduling detailed post restoration surveys (Hervouet et al., 2011; Carbonneau et al., 2012). The speed and flexibility of UAV deployment, besides its low cost, makes this platform a potentially valuable tool in vegetation monitoring at reach scale 

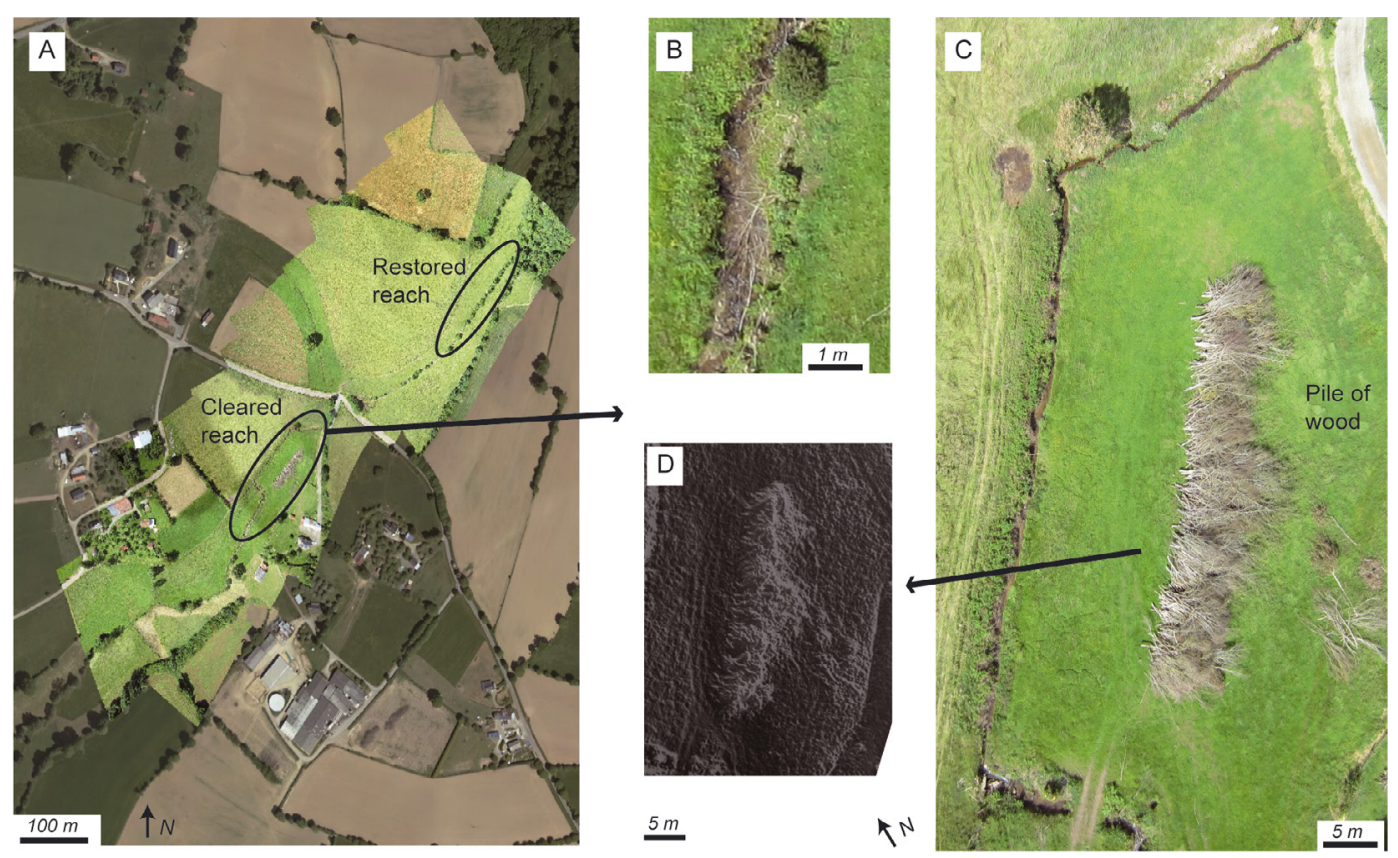

Figure 8

A) mosaic built with UAV images (overlay with the IGN orthophotographies), B) Oir channel (see piles of wood due to riparian vegetation clearance), C) cleared reach, D) DSM of the pile of wood automatically generated by the Agisoft PhotoScan software.

(Lejot et al., 2007; Dunford et al., 2009; Carbonneau et al., 2012). At network scale, radar and LiDAR provide wider scenes than UAV but data-treatment still needs high levels of technicality and access to specific software (Table I). The high cost of LiDAR data acquisition and extensive preprocessing phases are the main limitations to using these remotely sensed data extensively. In addition, LiDAR pulses emitted in the visible and near infrared ranges of the spectrum do not penetrate surface water (Töyrä and Pietroniro, 2005) and have difficulty penetrating dense vegetation cover. Lastly, lasers used for vegetation studies generally measure information in optical wavelengths in the range of $0.8-1.600 \mu \mathrm{m}$. The main limitation of working in these wavelengths is absorption by clouds, which impedes the use of these devices during overcast conditions (Lefsky et al., 2002; St-Onge, 2004). Height and intensity images derived from LiDAR data correctly map vegetation strata and broad vegetation types from structural parameters, but do not succeed in discriminating species in heterogeneous riparian corridors. Data fusion of very high resolution remote sensing images and LIDAR data is needed to achieve this (Forzieri et al., 2010). Different systems have a common disadvantage because no (or few) historical data are available for retrospective studies.

To characterize ephemeral parameters along stream banks, optical remotely sensed data (such as airborne or UAV images) are limited to cloud-free periods and to describing the top layer of the vegetation strata because penetration depth is very small (Marechal et al., 2012). Although radar is not sensitive to visibility conditions and can register information by day or night and through smoke and cloud cover, the spatial resolution of radar imagery that has been used until now was too low to investigate riparian vegetation with a sufficient level of precision (Dufour et al., 2012). Fine resolution SAR datasets show great potential for riparian mapping and monitoring in this respect.

To provide fully operational tools some progress is needed, notably in terms of data treatment to develop more automatic procedures to extract information from images and to calculate indicators (see for example: Carbonneau et al., 2009; Johansen et al., 2010; Wiederkehr et al., 2010; Aguiar et al., 2011; Tormos et al., 2011). Moreover, the information collected by sensors can be enhanced. For example, in the case of UAV, some developments can be expected with infra-red (Lelong et al., 2008; Lobo, 2009), real-time generation of 3-D maps systems 
Table II

Main advantages and limitations of image sources.

\begin{tabular}{|c|c|c|}
\hline & Advantages & Limitations \\
\hline \multirow[t]{2}{*}{ LiDAR } & $\begin{array}{l}\text { - 3D vegetation visualization and } \\
\text { mapping } \\
\text { - Enhancement of } 2 \mathrm{D} \text { riparian } \\
\text { vegetation mapping }\end{array}$ & $\begin{array}{l}\text { - Acquisition costs } \\
\text { - 3D mapping (still in progress) } \\
\text { - No penetration in dense } \\
\text { vegetation }\end{array}$ \\
\hline & $\begin{array}{l}\text { - Separation of ground and } \\
\text { vegetation }\end{array}$ & $\begin{array}{l}\text { - No penetration in water bodies } \\
\text { - Large data size (time computing) } \\
\text { - Historical data not available }\end{array}$ \\
\hline radar (TerraSAR-X) & $\begin{array}{l}\text { - Very High spatial and temporal } \\
\text { resolution } \\
\text { - Numerous data mode } \\
\text { acquisitions for multi-scale } \\
\text { analysis } \\
\text { - Non sensitive to clouds } \\
\text { - Large coverage area }\end{array}$ & \begin{tabular}{|l|} 
- Full polarimetric data is not \\
available \\
- Studies in development (few investi- \\
gations) \\
- Historical data only since 2007 \\
- Radar signal saturation with dense \\
vegetation \\
- Acquisition costs
\end{tabular} \\
\hline $\begin{array}{l}\text { UAV } \\
\text { (micro UAV } \\
\text { Sensefly model) }\end{array}$ & $\begin{array}{l}\text { - Low cost } \\
\text { - Very good spatial resolution } \\
\text { - Flexibility (potentially very high } \\
\text { repetitiveness in acquisitions) } \\
\text { - Data processing relatively easy } \\
\text { (but need memory large data set) }\end{array}$ & $\begin{array}{l}\text { - Small cover area } \\
\text { - Poor spectral resolution } \\
\text { - Provide digital surface model but not } \\
\text { digital elevation model } \\
\text { - Historical data not available (but } \\
\text { aerial photographs with a lower res- } \\
\text { olution can be used) }\end{array}$ \\
\hline
\end{tabular}

(Stefanik et al., 2011) and species scale classification (Dunford et al., 2009; Laliberte and Rango, 2011; Fernandes et al., 2013). Regarding LiDAR data, landscape features could be identified, extracted and mapped more satisfactorily from LiDAR 3D point clouds than from the 2D height and intensity images; however, 3D objects extraction based on object-oriented approaches is still at an experimental stage, while early studies are currently focusing on the segmentation of voxel (3D pixel) for the extraction of trees (Reitberger et al., 2009) or buildings (Keller et al., 2011). Moreover, most studies focus on LiDAR data analysis for topography, vegetation or built-up purposes, exclusively using the cloud points classified as "ground" and "above-ground" as well as intensity images. Yet, the characteristics of laser returns are not yet fully used, while intermediate returns contain useful information for vegetation structure characterization (Wang et al., 2012).

In terms of articulation with ground based approaches (Raven et al., 1998; Munné et al., 2003; Debruxelles et al., 2009), very few authors compared field based and geomatic based methods. However image analysis is not a way to replace field work. We believe it provides some complementary sets of data (i) to combine with field information and (ii) to enlarge studied area (Rheinhardt et al., 2007; Brooks et al., 2009; Dufour et al., 2012). Indeed, although we provide illustrations that recent improvements in remote sensing science can provide 3D information for narrow strips of riparian vegetation with high temporal resolution, some variables (e.g. composition of understory layer, tree age, flood marks, presence of litter...) are still difficult or impossible to collect through remote sensing. Thus a detailed assessment of specificities and complementarities is still needed in terms of indicators available, method cost and results accuracy. Considering the amount of time spent calibrating and validating the results, remote sensing approach is notably valuable for large scale studies (Coroi et al., 2006; Johansen et al., 2007b).

\section{ACKNOWLEDGEMENTS}

Rennes metropolis for funding UAV project. The master of Charles Trolle (UAV project) was funded by the Atlantic Aquatic Conservation Resources project (AARC Intereg 
Ivb, 2009-2012) and he benefits also of collaborations with the bilateral ONEMA-INRA programs and the french National Strategy on Biodiversity (SNB, Ministry of Ecology).

\section{REFERENCES}

Aguiar F.C., Fernandes M.R. and Ferreira M.T., 2011. Riparian vegetation metrics as tools for guiding ecological restoration in riverscape set. Knowl. Managt. Aquatic Ecosyst., 402, 21.

Antonarakis A.S., Richards K.S. and Brasington J., 2008a. Object-based land cover classification using airborne LiDAR. Remote Sens. Environ., 112, 2988-2998.

Antonarakis A.S., Richards K.S., Brasington J., Bithell M. and Muller E., 2008b. Retrieval of vegetative fluid resistance terms for rigid stems using airborne LiDAR. J. Geophys. Res., 113, G02S07.

Arroyo LA., Johansen K., Armston J. and Phinn S., 2010. Integration of LiDAR and QuickBird imagery for mapping riparian biophysical parameters and land cover types in Australian tropical savannas. For. Ecol. Manag., 259, 598-606.

Axelsson P., 1999. Processing of laser scanner data-algorithms and applications. ISPRS-J. Photogramm. Remote Sens., 54, 138-147.

Brooks R., McKenney-Easterling M., Brinson M., Rheinhardt R., Havens K., O’Brien D., Bishop J., Rubbo J., Armstrong B. and Hite J., 2009. A Stream-Wetland-Riparian (SWR) index for assessing condition of aquatic ecosystems in small watersheds along the Atlantic slope of the eastern U.S. Environ. Monit. Assess., 150, 101-117.

Carbonneau P.E. and Piégay H., 2012. Fluvial Remote Sensing for Science and Management. John Wiley \& Sons, $440 \mathrm{p}$.

Carbonneau P.E., Dugdale S.J. and Clough S., 2009. An Automated georeferencing tool for watershed scale fluvial remote sensing. River Res. App., 26, 650-658.

Carbonneau P.E., Piégay H., Lejot J., Dunford R. and Michel K., 2012. Hyperspatial imagery in riverine environments. In: Carbonneau R.E. and Piégay H. (eds.), Fluvial Remote Sensing for Science and Management, Wiley, 163-191.

Coroi M., Sheehy Skeffington M., Giller P., Gormally M. and O'Donovan G., 2006. Using GIS in the mapping and analysis of the landscape and vegetation patterns along streams in Southern Ireland. Biol. Environ.-Proc. R. Irish Acad., 106 B, 287-300.

Debruxelles N., Claessens H., Lejeune P. and Rondeux J., 2009. Design of a watercourse and riparian strip monitoring system for environmental management. Environ. Monit. Assess., 156, 435-450.

Dowling R. and Accad A., 2003. Vegetation classification of the riparian zone along the Brisbane River, Queensland, Australia, using light detection and ranging (LiDAR) data and forward looking digital video. Can. J. Remote Sens., 29, 556-563.

Dufour S. and Piégay H., 2009. From the myth of a lost paradise to targeted river restoration: forget natural references and focus on human benefits. River Res. App., 25, 568-581.

Dufour S., Muller E., Straastma M. and Corgne S., 2012. Image uses for riparian vegetation study and management. In: Carbonneau R.E. and Piégay H. (eds.), Imagery and river management: Recent advances and challenging issues, Wiley, 215-239.

Dunford R., Michel K., Gagnage M., Piégay H. and Trémelo M.L., 2009. Potential and constraints of UAV technology for the characterisation of Mediterranean riparian forest. Int. J. Remote Sens., 30, 4915-4935.

Farid A., Goodrich D.C. and Sorooshian S., 2006. Using Airborne Lidar to Discern Age Classes of Cottonwood Trees in a Riparian Area. West. J. Appl. For., 21, 149-158.

Feld C.K., 2012. Response of three lotic assemblages to riparian and catchment-scale land use: implications for designing catchment monitoring programmes. Freshwater Biol., 58, 715-729.

Fernandes M.R., Aguiar F.C., Ferreira M.T. and Cardoso Pereira J.M., 2013. Spectral separability of riparian forests from small and medium-sized rivers across a latitudinal gradient using multispectral imagery. Int. J. Remote Sens., 33, 2375-2401.

Forget G., Carreau C., Le Coeur D. and Bernez I., 2013. Ecological Restoration of Headwaters in a Rural Landscape (Normandy, France): A Passive Approach Taking Hedge Networks into Account for Riparian Tree Recruitment. Restor. Ecol., 21, 96-104. 
Forzieri G., Moser G., Vivoni E., Castelli F. and Canovaro F., 2010. Riparian Vegetation Mapping for Hydraulic Roughness Estimation Using Very High Resolution Remote Sensing Data Fusion. J. Hydraul. Eng., 136, 855-867.

Fritz T., Eineder M., Lachaise M., Roth A., Breit H., Schättler B. and Huber M., 2007. TerraSAR-X Ground Segment. Level 1b Product Format Specification. Annex B. DLR. Doc. TX-GS-DD-3307.

Geerling G.W., Vreeken-Buijs M.J., Jesse P., Ragas A.M.J. and Smits A.J.M., 2009. Mapping river floodplain ecotopes by segmentation of spectral (CASI) and structural (LiDAR) remote sensing data. River Res. App., 25, 895-813.

Goetz S.J., 2006. Remote sensing of riparian buffers: past progress and future prospects. J. Am. Water Resour. Assoc., 42, 133-143.

Hansen A. and Rotella J.J., 2000. Bird responses to forest fragmentation. In: Knight R.L., Smith F.W., Romme W.H. and Buskirk S.W. (eds.), Forest Fragmentation in the Southern Rockies. Boulder, University Press of Colorado, 201-219.

Hardin P.J. and Jensen R.R., 2011. Introduction-Small-Scale Unmanned Aerial Systems for Environmental Remote Sensing. GISci. Remote Sens., 48, 1-3.

Hervouet A., Dunford R., Piegay H., Belletti B. and Tremelo M.L., 2011. Analysis of Post-flood Recruitment Patterns in Braided Channel Rivers at Multiple Scales Based on an Image Series Collected by Unmanned Aerial Vehicles, Ultra-light Aerial Vehicles, and Satellites. G/Sci. Remote Sens., 48, 50-73.

Johansen K., Tiede D., Blaschke T., Arroyo L.A. and Phinn S., 2011. Automatic Geographic Object Based Mapping of Streambed and Riparian Zone Extent from LiDAR Data in a Temperate Rural Urban Environment, Australia. Remote Sens., 3, 1139-1156.

Johansen K., Coops N.C., Gergel S.E. and Stange Y., 2007a. Application of high spatial resolution satellite imagery for riparian and forest ecosystem classification. Remote Sens. Environ., 110, 29-44.

Johansen K., Phinn S. and Witte C., 2010. Mapping of riparian zone attributes using discrete return LiDAR, QuickBird and SPOT-5 imagery: Assessing accuracy and costs. Remote Sens. Environ., 114, 2679-2691.

Johansen K., Phinn S., Dixon I., Douglas M. and Lowry J., 2007b. Comparison of image and rapid field assessments of riparian zone condition in Australian tropical savannas. For. Ecol. Manag., 240, $42-60$.

Keller P., Kreylos O., Vanco M., Hering-Bertram M., Cowgill E.S., Kellogg L.H., Hamann B. and Hagen H., 2011. Extracting and Visualizing Structural Features in Environmental Point Cloud LiDaR Data Sets. In: Pascucci V., Tricoche X., Hagen H. and Tierny J. (eds.), Topological Methods in Data Analysis and Visualization: Theory, Algorithms, and Applications, Springer-Verlag, Heidelberg, Germany, 179-192.

Laliberte A.S. and Rango A., 2011. Image Processing and Classification Procedures for Analysis of Subdecimeter Imagery Acquired with an Unmanned Aircraft over Arid Rangelands. GISci. Remote Sens., 48, 4-23.

Lee J.S. and Pottier E., 2009. Polarimetric Radar Imaging: From basics to applications. CRC Press, Taylor \& Francis, $397 \mathrm{p}$.

Lee J.S., 1981. Refined filtering of image noise using local statistics. Comput. Graph. Image Process., 4, 380-389.

Lefsky M.A., Cohen W.B., Parker G.G. and Harding D.J., 2002. Lidar remote sensing for ecosystem studies. Bioscience, 52, 19-30.

Lejot J., Delacourt C., Piégay H., Trémélo M.L. and Fournier T., 2007. Very high spatial resolution imagery for reconstructing channel bathymetry and topography from an unmanned controlled platform. Earth Surf. Process. Landf., 32, 1705-1725.

Lelong C.D., Burger P., Jubelin G., Roux B., Labbé S. and Baret F., 2008. Assessment of Unmanned Aerial Vehicles Imagery for Quantitative Monitoring of Wheat Crop in Small Plots. Sensors, 8, 3557-3585.

Lobo A., 2009. Testing low-altitude infrared digital photography from a mini-UAV to retrieve information for biological conservation. Reports on Environmental Sciences 9, available on http://www. recercat.net/handle/2072/16100.

Lopez-Sanchez J.M., Ballester-Berman J.D. and Hajnsek I., 2009. Rice monitoring in Spain by means of time series of TerraSAR-X Dual-Pol images. Proc. of the 4th Int. Workshop on Science and Applications of SAR Polarimetry - PollnSAR 2009, Frascati, Italy (ESA SP-668, April 2009). 
Malanson G.P., 1993. Riparian landscapes. Cambridge University Press, Cambridge, UK, 296 p.

Marechal C., Pottier E., Hubert-Moy L. and Rapinel S., 2012. One Year Wetland Survey Investigations from Quad-Pol RADARSAT-2 Time-Series SAR Images. Can. J. Remote Sens., 38, 240-252.

Munné A., Prat N., Sola C. and Bonada N., and Rieradevell M., 2003. A simple field method for assessing the ecological quality of riparian habitat in rivers and streams: a QBR index. Aquat. Conserv. Mar. Freshw. Ecosyst., 13, 147-163.

Naiman R.J., Deìcamps H. and McCLain M., 2005. Riparia, ecology, conservation, and management of streamside communities. Academic Press, Elsevier, San Diego 430 p.

Ormerod SJ., 2004. A golden age of river restoration science? Aquat. Conserv. Mar. Freshw. Ecosyst., 14, 543-549.

Palmer M.A., Bernhardt E.S., Allan J.D., Lake P.S., Alexander G., Brooks S., Carr J., Clayton S., Dahm C., Follstad Shah J., Galat D.J., Gloss S., Goodwin P., Hart D.H., Hassett B., Jenkinson R., Kondolf G.M., Lave R., Meyer J.L., O’Donnell T.K., Pagano L., Srivastava P. and Sudduth E., 2005. Standards for ecologically successful river restoration. J. Appl. Ecol. , 42, 208-217.

Raven P.J., Holmes N.T.H., Dawson F.H. and Everard M., 1998. Quality assessment using River Habitat Survey data. Aquat. Conserv., 8, 477-499.

Reitberger J., Schnörr C., Krzystek P., and Stilla U., 2009. 3D segmentation of single trees exploiting full waveform LiDAR data. ISPRS-J. Photogramm. Remote Sens., 64, 561-574.

Rheinhardt R., Brinson M., Brooks R., McKenney-Easterling M., Masina Rubbo J., Hite J., Armstrong B., 2007. Development of a reference-based method for identifying and scoring indicators of condition for coastal plain riparian reaches. Ecol. Indic., 7, 339-361.

Stefanik K.S., Gassaway J.C., Kochersberger K. and Abbott A.L., 2011. UAV-Based Stereo Vision for Rapid Aerial Terrain Mapping. GISci. Remote Sens., 48, 24-49.

St-Onge B., 2004. L'altimétrie laser à balayage. Revue Internationale de Géomatique, 14, 531-558.

Tormos T., Kosuth P., Durrieu S., Dupuy S., Villeneuve B. and Wasson J.G., 2012. Object-based image analysis for operational fine-scale regional mapping of land cover within river corridors from multispectral imagery and thematic data. Int. J. Remote Sens., 33, 4603-4633.

Tormos T., Kosuth P., Durrieu S., Villeneuve B. and Wasson J.G., 2011. Improving the quantification of land cover pressure on stream ecological status at the riparian scale using High Spatial Resolution Imagery. Phys. Chem. Earth, 36, 549-559.

Töyrä J., and Pietroniro A., 2005. Towards operational monitoring of a northern wetland using geomatics-based techniques. Remote Sens. Environ., 97, 174-191.

Turner D.P., Cohen W.B., Kennedy R.E., Fassnacht K.S. and Briggs J.M., 1999. Relationship between leaf area index and Landsat TM spectral vegetation indices across three temperate zone sites. Remote Sens. Environ., 70, 52-68.

Vierling K.T., Vierling L.A., Gould W.A., Martinuzzi S. and Clawges R.M., 2008. Lidar: shedding new light on habitat characterization and modeling. Front. Ecol. Environ., 6, 90-98.

Wang S.Y., Cui X.M., Yuan D.B., Jin J.J. and Zhang Q., 2012. Classification of Airborne Lidar Data by Echo. Key Eng. Mater., 500, 696-700.

Wasson J.G., Villeneuve B., Lital A., Murray-Bligh J., Dobiasova M., Bacikova S., Timm H., Pella H., Mengin N. and Chandesris A., 2010. Large-scale relationships between basin and riparian land cover and the ecological status of European rivers. Freshwater Biol., 55, 1465-1482.

Wiederkehr E., Dufour S. and Piégay H., 2010. Localisation et caractérisation des géomorphosites fluviaux à l'échelle des réseaux hydrographiques, exemples d'applications géomatiques dans le bassin de la Drôme. Géomorphologie : relief, processus, environnement, 2, 175-188.

Yang X., 2007. Integrated use of remote sensing and geographic information systems in riparian vegetation delineation and mapping. Int. J. Remote Sens., 28, 353-370. 